\title{
Evolution AND PALEOENVIRONMENTAL RECONSTITUTION OF THE SOUTHERN ZoNE OF THE RIO DE JANEIRo City (SE BRAZIL)
}

\section{Guilherme loriato Potratz ${ }^{1,2}$, Felipe Saliba de SouZa e Almeida ${ }^{3}$, João Wagner de Alencar Castro ${ }^{4}$, MARIA Virginia ALVES MARTINS ${ }^{3,4}$ AND MAURo CESAR GERALDES ${ }^{3}$}

1 Universidade do Estado do Rio de Janeiro, Programa de Pós-graduação em Geociências, Rua São Francisco Xavier, 524, Maracanã, Rio de Janeiro, Brazil

2 Universidade Federal do Rio de Janeiro, Programa de Especialização em Geologia do Quaternário, Museu Nacional, Quinta da Boa Vista, São Cristóvão, Rio de Janeiro, Brazil

3 Universidade do Estado do Rio de Janeiro, UERJ, Faculdade de Geologia, Rua São Francisco Xavier, 524, Maracanã, Rio de Janeiro, Brazil

4 Universidade de Aveiro, GeoBioTec, Departamento de Geociências, Campus de Santiago, 3810-193 Aveiro, Portugal

5 Universidade Federal do Rio de Janeiro, UFRJ, Museu Nacional, Quinta da Boa Vista, São Cristóvão, Rio de Janeiro, Brazil

\section{* Corresponding author, geraldes@uerj.br}

Received on 28 May 2019

Received in revised form on 19 June 2019

Accepted on 20 June 2019

Editor: Maria Antonieta da Conceição Rodrigues, Universidade do Estado do Rio de Janeiro

\section{Abstract}

Paleoenvironmental reconstructions in coastal environments have been carried out using indicators of relative sea level oscillation (RSL), among them, mollusk shells, beachrocks and sedimentary records. Data from eleven geological-geotechnical drilling cores (from $15 \mathrm{~m}$ to $30 \mathrm{~m}$ long) distributed along the Ipanema - Leblon coastline and on the edge of the Rodrigo de Freitas Lagoon and respective stratigraphic profiles were analyzed in this work. Ten radiocarbon ages obtained from shell samples calibrated to eliminate the effect of reservoir were used to perform the time evolution of the study area.

The obtained results allowed to identify five distinct stages on the sedimentary evolution of the Southern Zone of the

\section{Introduction}

Quaternary period was marked by impressive climatic oscillations and large variations of the relative sea level (RSL), which were responsible for the construction of current worldwide coastal sedimentary environments, such as beaches, tidal plains and lagoons (Elias, 2007; Flemming et al., 2017).

Until recently there was a worldwide geological correlation project aiming to determine an eustatic curve for the Holocene (Suguio et al., 1985; Pirazzoli, 1991). This project was quickly abandoned, since the field work showed
Citation:

Potratz, G.L., Souza e Almeida, F.S., Castro, J.W.A., Alves Martins, M.V.A, Geraldes, M.G., 2019. Evolution and Paleoenvironmental Reconstitution of the Southern Zone of the Rio de Janeiro City (SE Brazil). Journal of Sedimentary Environments, 4 (2): 189-198.
Rio de Janeiro City related to the Holocene RSL variations: the first stage under continental environmental conditions, with sea level approximately $4.5 \mathrm{~m}$ below the current; the second stage corresponding to a paleo-cove formed due to the sea level rising; the third stage associated with the midHolocene maximum transgression, in which the entire study area was flooded; the fourth stage following the gradual lowering of the RSL and marked by the formation of a paleo-bay; the fifth stage corresponding to the current configuration of the coastline.

Keywords: Relative sea level change. Quaternary. Marine Sedimentation. Coastline evolution. 2D-Model. that it is impossible to make such correlations due to different regional records of sea level changes (Suguio et al., 1985; Khan et al., 2015). Paleo-sea level variations included eustasy (global sea level change) causing alterations in the volume of oceanic basins (tectono-eustasy), of the sea water (glacial eustasy) and even the variation of oceanic levels (geoidal eustasy), but also variations in the ground level due to tectonism or isostasy (Mörner, 1984; Fairbanks, 1989) and also to local geomorphological features (Ramsay and Cooper, 2002). Faced the impossibility of constructing sea 
level global curves, the research began to be developed locally.

In Brazilian coast, RSL change are recorded along the littoral (e.g. Bezerra et al., 2003; Boski et al., 2016; Jesus et al., 2017; Angulo et al., 2006, 2018), being identified by both vertical and horizontal projection indicators (Castro et al., 2014). Along the coast of Rio de Janeiro State, several authors have identified records of RSL variations along the Holocene such as, Lamego (1945), Roncarati and Neves (1976), Flexor et al. (1984), Maia et al. (1984), Suguio et al. (1985), Shipowner (1997), Castro et al. (2006, 2012, 2014), Dias et al. (2009), Mansur et al. (2011), Roncarati and Carelli (2012), Cunha et al. (2017), Jesus et al. (2017) among others. These authors observed such evidences in the coastal segment between Parati and Cabo Frio (Fig. 1).

Lamego (1945) performed one of the first works about RSL change and described the structure of the coast of the Rio de Janeiro State and the evolutionary cycle of the Rio de Janeiro lagoons. This author described peculiarities of Sepetiba Bay (Fig. 1B) and aspects related to the formation of Maricá (Fig. 1E), Saquarema (Fig. 1F) and Araruama lagoons (Fig. 1G).

In the region of Sepetiba Bay (Fig. 1B) it is possible to highlight several evidences of RSL variation. Roncarati and Carelli (2012) proposed four stages for the formation of this bay, associated to RSL fluctuations. Villena et al. (2012) observed evidences of RSL through the analysis of geophysical profiles and sediment cores, including foraminifera in specific sedimentary environments and palynological contents. Carelli et al. (2012) described the occurrence of sandy strings at 4 and 5 meters above current sea level in the coastal plain of Itaguaí and associated them with higher sea levels in the geological past. Yet, Pereira and Santos (2012) described two transgressive/regressive cycles for the Holocene in the Guaratiba mangrove, based on the description of mollusks found in this area.

Roncarati and Neves (1976) described the development of the coastal plain of Jacarepaguá (Fig. 1C) and associated the formation of the internal and external littoral sand spits with two transgressive events, which gave rise to the formation of Jacarepaguá, Camimim, Tijuca and Marapendi lagoons by the partial silting of old lagoons. Subsequently, Maia et al. (1984), Calheiros (2006) and Pereira et al. (2012), contributed with sedimentological, geophysical and geochronological studies obtained in this area, corroborating the hypothesis that the RSL changes influenced the sedimentary processes in this coastal plain.

Suguio et al. (1985) recognized 17 positions of the RSL, in the segment between Parati and Angra (Fig. 1A), which allowed the elaboration of a curve of the RSL change for this sector corresponding to the last 2,500 years. These authors still identified two maximum RSL levels, of 3 meters and 4.8 meters above the current sea level.

Shipowner (1997) related the genesis of two marine terraces in Guanabara Bay to the Holocene marine transgressions (Fig. 1D). This author described and related the presence of fluvial clays intercalating the sands of the Caceribu Formation to lower marine levels than the current during the sedimentary infilling of what is now the Guanabara Bay.

Large number of works related to RSL changes were performed in the lakes region of the Rio Grande do Sul State. Several authors identified past levels of paleobeaches along the littoral of this region, mainly using the beachrock alignments (such as Mansur et al., 2011; Castro et al., 2012, 2014; Cunha et al., 2017; Malta et al., 2017; Malta, 2017). In addition, to beachrocks, evidences such as, marine carvings, hedgehog marks, marine terraces, vermicides, paleobarnacles and accumulation of seashells of the Tauá Reserve, were also used as evidences of RSL changes in the lakes region (Castro et al., 2006; Dias et al., 2009; Dias, 2009). These kinds of evidences have been also observed in other regions of the world (Rostami et al., 2000; Patzkowsky and Holland, 2012).

Castro et al. (2014) proposed a Holocene RSL curve for the coast of the Rio de Janeiro State, which was later corroborated by the works of Malta et al. (2017) and Malta (2017). These authors documented a negative RSL record, at the end of the Pleistocene and the beginning of the Holocene.

This work aims to understand the geological-stratigraphic evolution of the region between the Rodrigo de Freitas Lagoon and the Atlantic Ocean, at south of Rio de Janeiro City (SE, Brazil). It was based on a significant number of sediment cores (11) collected along the Ipanema - Leblon coastline and on the edge of the Rodrigo de Freitas Lagoon (Fig. 1). Ten radiocarbon ages were used to reconstruct the paleoenvironmental evolution and local dynamics.

\section{Study Area}

In the Rio de Janeiro State, the littoral sedimentary environments are characterized by extensive Quaternary plains, mainly between the Guanabara Bay and the Itabapoana River, close of the frontier with the Espírito Santo State (Fig. 1). These coastal plains are limited by rocks of the crystalline basement and terraces of the Barreiras Formation, which is extended over almost the entire Brazilian coast (Cunha et al., 2017). Suguio (2003) described these plains as low-gradient depositional geomorphological surfaces, where prevailed subaquatic sedimentation processes, in marginal marine environments.

In this area, there is a contrast between the crystalline basement units, belonging to the Oriental Terrain and Ribeira Belt (Heilbron et al., 2004), and the Cenozoic deposits. The outcrop of basement rocks belongs to the Cordeiro and Rio de Janeiro suites, together with the paragneiss of the São Fidélis Group (Heilbron et al., 2004). Cenozoic sedimentary coverings are composed by coastal, alluvial and anthropogenic deposits (Heilbron et al., 2016). 


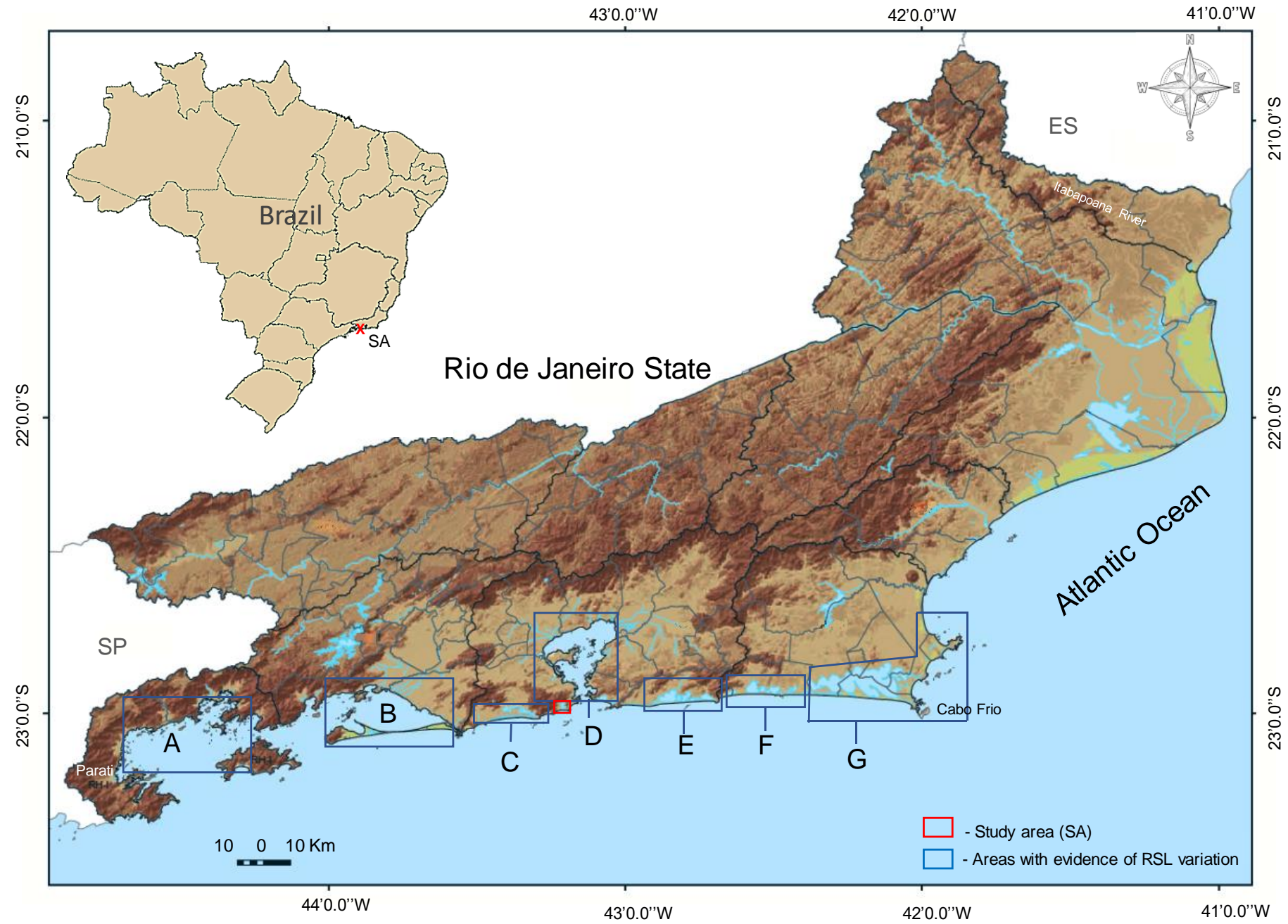

Fig. 1. Location map of the study area, in the Southern Zone of the Rio de Janeiro City (SE Brazil). Segments of the Rio de Janeiro coast, in which indicators of RSL variations along Holocene were identified, are represented. Adapted from INEA (Instituto Estadual do Ambiente) geomorphic map of Rio de Janeiro (https://www.inea.rj.gov.br/portalgeoinea).

In terms of geomorphology, three morpho-structural units were defined by Dantas (2001) in the study area: the coastal and inland unities, which cover a relatively (WSWENE) aligned set of mountains between the bay and the coastal slopes, being the coastal massifs the eastern border of the Guanabara Graben; the coastal plains and the coastalfluvial -alluvial - marine coastal plains and; series of sandspits originated as the result of coastal strings stacking, originated from sedimentary processes following RSL oscillations. The relief of this unit is smooth and marked by alternations of parallel sandy ridges with flooded depressions.

At present, the processes of sediment addition and removal on the coastline of the Southern Zone of the Rio de Janeiro City are strongly influenced by oceanographic factors, being waves, tides and longshore currents the main driving forces. Two main wave climates act on the Leblon -
Ipanema beach segment during the summer and winter seasons (Coutinho, 2007). In summer, the climatic and sea conditions are less energetic and waves of S/SE quadrant are predominant (Coutinho, 2007). During the winter period, in which the waves are more energetic, predominate waves from the S/SW quadrant, associated with strong swell (Coutinho, 2007). The East-West orientation of this beach segment causes drift currents, resulting from storm waves, that remobilize the sediments eastwards, accumulating them in the Arpoador beach, while the currents of southeast waves remobilize the sediments toward the Leblon beach.

\section{Materials and Methods}

In this work, the Holocene paleoenvironmental reconstruction and evolution model was developed in the Southern Zone of the Rio de Janeiro City, including Rodrigo 
de Freitas Lagoon, Jardim Botânico, Humaitá, Gávea, Leblon and Ipanema neighborhoods (Fig. 2). Eleven geological-geotechnical drilling cores, spatially distributed in a rectangle bounded by the coordinates $43^{\circ} 14^{\prime} \mathrm{W}$ to $43^{\circ} 11^{\prime} \mathrm{W}$ and $22^{\circ} 58^{\prime} \mathrm{S}$ to $23^{\circ} 0^{\prime} \mathrm{S}$, along the Ipanema-Leblon coastline and at the edge of the Rodrigo de Freitas Lagoon, were analyzed in this work. The geographic coordinates (latitude and longitude) and the identification of the analyzed cores are presented in Table 1. Stratigraphic profiles were performed, scanned and later vectored using the Corel Draw software, version X7.

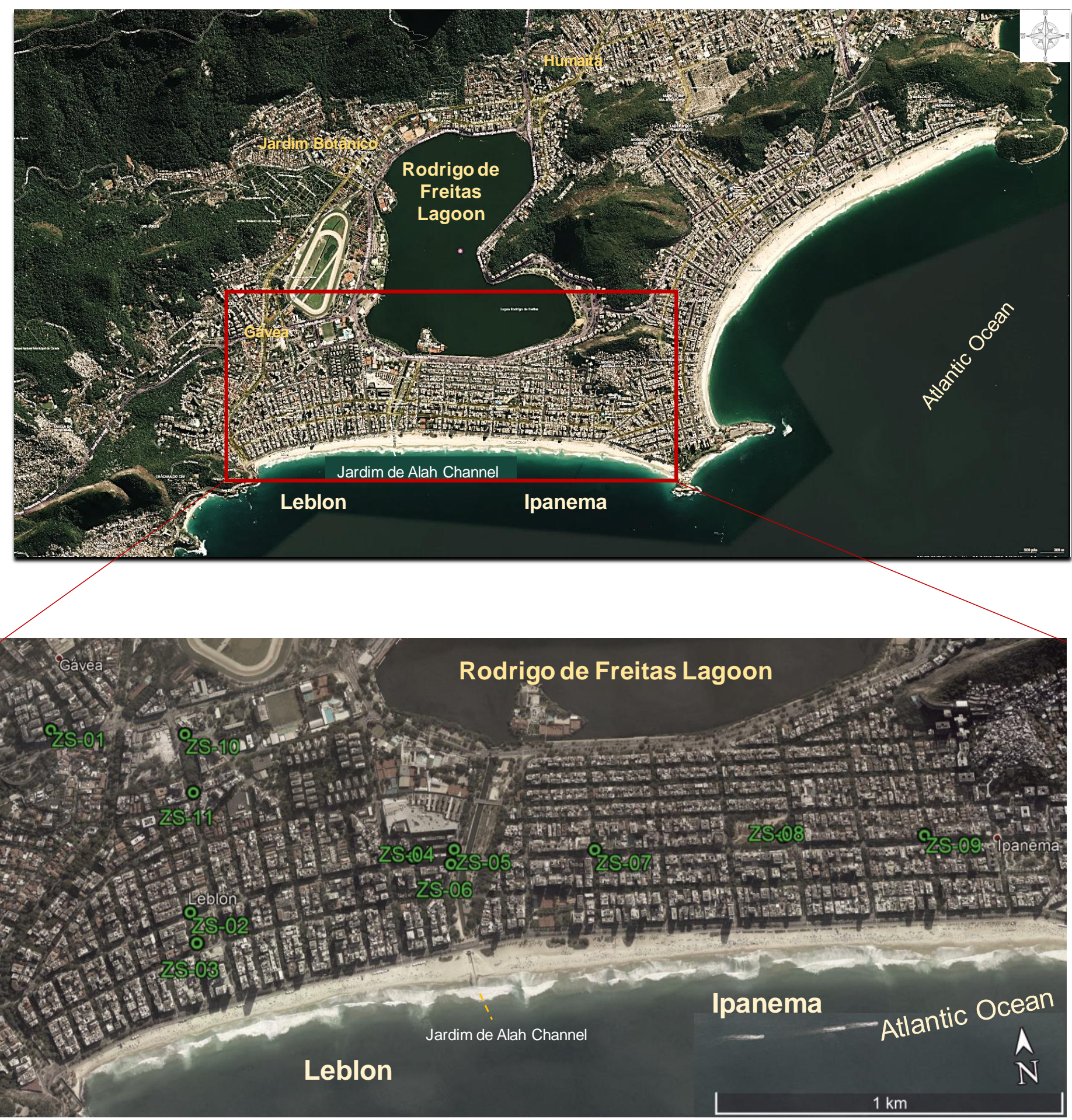

Fig. 2. Study region between the Rodrigo de Freitas Lagoon and the Atlantic Ocean, at south of Rio de Janeiro City (SE Brazil) and the location of the analyzed profiles (ZS01-ZS11). Adapted from Google Earth. 
Tab. 1. Identification of geological-geotechnical drilling cores. The coordinates (UTM) were collected in the horizontal datum WGS84 , zone $23 \mathrm{~K}$.

\begin{tabular}{|l|l|l|}
\hline Core & $\begin{array}{c}\text { Longitude } \\
\text { (UTM) }\end{array}$ & $\begin{array}{c}\text { Latitude } \\
\text { (UTM) }\end{array}$ \\
\hline ZS-01 & $681589 \mathrm{~m} \mathrm{E}$ & $7456982 \mathrm{~m} \mathrm{~S}$ \\
\hline ZS-02 & $682057 \mathrm{~m} \mathrm{E}$ & $7457078 \mathrm{~m} \mathrm{~S}$ \\
\hline ZS-03 & $682078 \mathrm{~m} \mathrm{E}$ & $7456977 \mathrm{~m} \mathrm{~S}$ \\
\hline ZS-04 & $682770 \mathrm{~m} \mathrm{E}$ & $7457183 \mathrm{~m} \mathrm{~S}$ \\
\hline ZS-05 & $682902 \mathrm{~m} \mathrm{E}$ & $7457196 \mathrm{~m} \mathrm{~S}$ \\
\hline ZS-06 & $682888 \mathrm{~m} \mathrm{E}$ & $7457148 \mathrm{~m} \mathrm{~S}$ \\
\hline ZS-07 & $683353 \mathrm{~m} \mathrm{E}$ & $7457142 \mathrm{~m} \mathrm{~S}$ \\
\hline ZS-08 & $683967 \mathrm{~m} \mathrm{E}$ & $7457122 \mathrm{~m} \mathrm{~S}$ \\
\hline ZS-09 & $684422 \mathrm{~m} \mathrm{E}$ & $7457073 \mathrm{~m} \mathrm{~S}$ \\
\hline ZS-10 & $682034 \mathrm{~m} \mathrm{E}$ & $7457700 \mathrm{~m} \mathrm{~S}$ \\
\hline ZS-11 & $682064 \mathrm{~m} \mathrm{E}$ & $7457485 \mathrm{~m} \mathrm{~S}$ \\
\hline
\end{tabular}

For this work, ten radiocarbon ages of mollusk shells were obtained in Beta Analytic. Mollusk shells, for radiocarbon analysis, were collected between $4.0 \mathrm{~m}$ and 27 $m$ depth, in cores ZS-01, ZS-02, ZS-04, ZS-05, ZS-06 and ZS-09. Calibration was performed with the Calib software, version 7.1, using the delta $\mathrm{R}$ value proposed by Alves et al. (2015).

The Holocene paleoenvironmental reconstruction of the Southern Zone of the Rio de Janeiro City was based on the interpretation of radiocarbon ages, geological data of the stratigraphic profiles and on altimetric data available on the IBGE website. The cartographic base used for the paleoenvironmental reconstruction was elaborated in the Quantum GIS software, version 7.2.2 (free). The altimetric data of the RSL curve proposed by Castro et al. (2014), for the coast of the Rio de Janeiro State, was considered.

Models of Holocene evolution proposed for regions close to the study area were used as reference for the reconstruction of the study area evolution, such as those proposed by: (a) Maia et al. (1984) and Pereira et al. (2012), for the Jacarepaguá coastal plain and; (b) Lamego (1945), Roncarati and Carelli (2012) and Pereira et al. (2012), for Sepetiba Bay.

\section{Results}

The stratigraphic profiles of the analyzed cores are presented in Fig. 3. In all profiles, the presence of material constituted by landfill was identified in the upper interval until 2.0 to 6.0 meters depth, related to the urbanization of the Southern Zone of the Rio de Janeiro City. Quartz sediments with granulation ranging from very fine to coarse sand were identified in seven profiles: ZS-01, ZS-02, ZS-03, ZS-07, ZS-08, ZS-09 and ZS-11. They make part of intervals ranging from 3.0 to $26 \mathrm{~m}$ depth.

In all the studied profiles, except the ZS-11 profile, layers of fragmented mollusk shells were identified in intervals between $14 \mathrm{~m}$ and $28 \mathrm{~m}$ depth. Pebbly sand intervals were also identified in the profiles ZS-01, ZS-02 and ZS-04, between $6.0 \mathrm{~m}$ and $14 \mathrm{~m}$ depth. Layers of muddy sand were recognized in the profiles ZS-03, ZS-07, ZS-08, ZS-10 and ZS-11, between $24 \mathrm{~m}$ and $30 \mathrm{~m}$ depth.

In several profiles were also identified intervals of silt, silt with fragments of mollusk shells, clay, clay rich in organic matter and oxidized clay. Alteration layers of the basement rocks were notorious in two profiles, ZS-01 and ZS-10. The crystalline basement, characterized by phacoidal gneisses (Rio de Janeiro Suite), was found in the profiles ZS-04, ZS05 and ZS-10, from $10 \mathrm{~m}$ to $18 \mathrm{~m}$ depth. It is important to note that in the ZS-05 profile a rocky basement block was identified in the middle of the sedimentary package.

Table 2 presents all information regarding radiocarbon dating and their respective corrections. Radiocarbon ages varied from 876 and 7,328 years cal BP (average probability) in the analyzed materials.

\section{Discussion}

Geological and geochronological data was synthesized on a 2D-paleoenvironmental reconstruction model. It proposes five Holocene sedimentation stages, which contributed to the development and evolution of the coastal plain of the Southern Zone of the Rio de Janeiro City, comprising the Rodrigo de Freitas Lagoon and Jardim Botânico, Humaitá, Gávea, Leblon and Ipanema regions. The five Holocene sedimentation stages are presented in Figure 4 and described below.

Stage 1. The first evolutionary stage of the studied coastal plain, concerning the Pleistocene-Holocene transition, occurred at about 11,400 years ago. The RSL was approximately $5.0 \mathrm{~m}$ below the current level, thus corroborating the work developed by Castro et al. (2014). At this stage, the continental sedimentation predominated in a fluvial system, whose main channel should have been tributary of the paleochannel of Guanabara (Ruellan, 1944), along with the advance of colluvial and alluvial-colluvial slope fans (Fig. 4A).

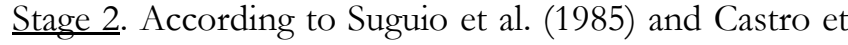
al. (2014) after the Pleistocene - Holocene transition, the RSL rose rapidly, reaching the present level at $\approx 7,500$ years cal BP. The progressive sea level rise caused the retreat of the drainage system and a large area, previously covered by continental sediments became drowned, generating a paleocove with sandy beaches in the inner zone (Fig. 4B). 

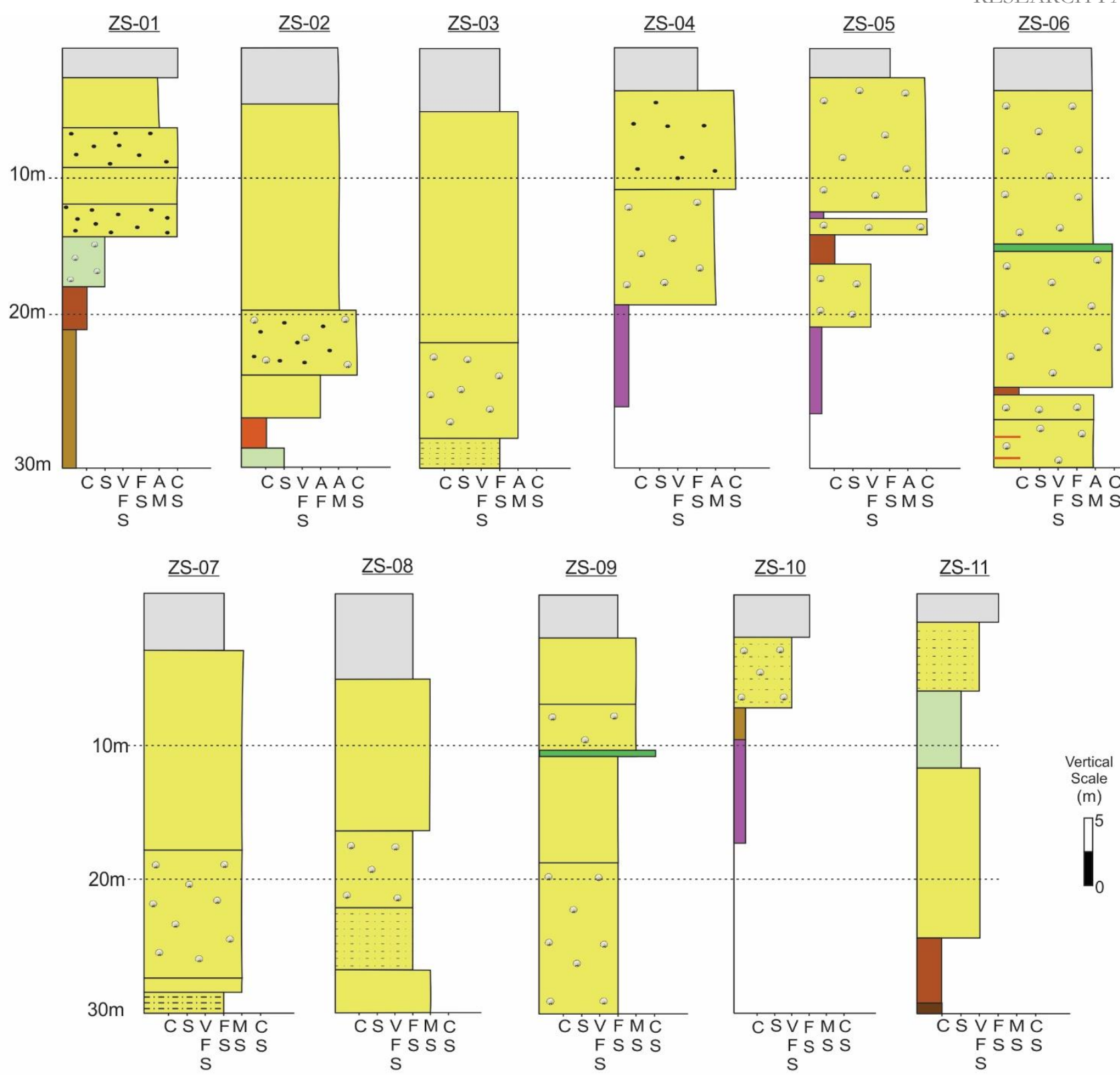

\section{LEGEND}

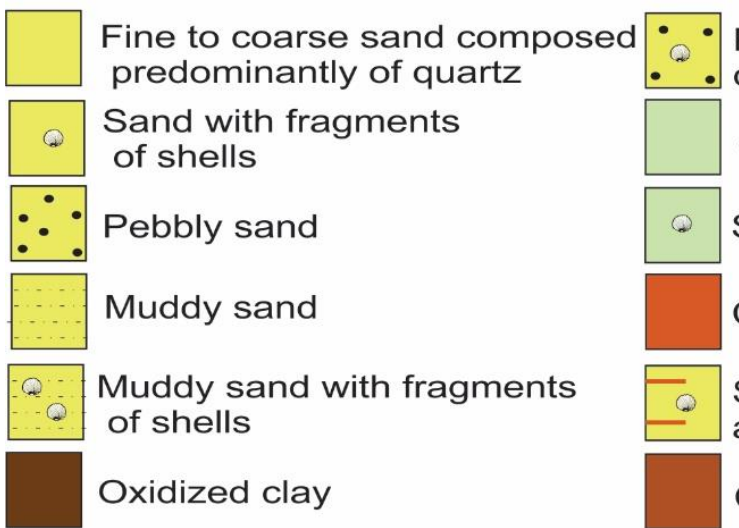

Pebbly sand with fragments of shells

Silt

Sand with fragments of shells

Silt with fragments of shells

Clay

Sand with fragments of shells and clay lenses

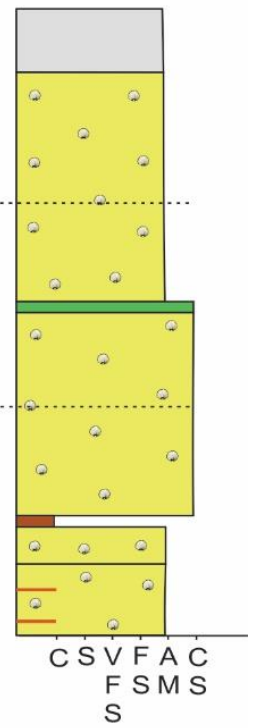

Clay rich in organic matter

Fig. 3. Stratigraphic profiles of the geological-geotechnical drilling cores, collected along the Ipanema-Leblon coastline and at the edge of the Rodrigo de Freitas Lagoon. Legend: C = Clay; S = Silt; VFS = Very Fine Sand; FS = Fine Sand; MS = Medium Sand; CS = Coarse Sand. 

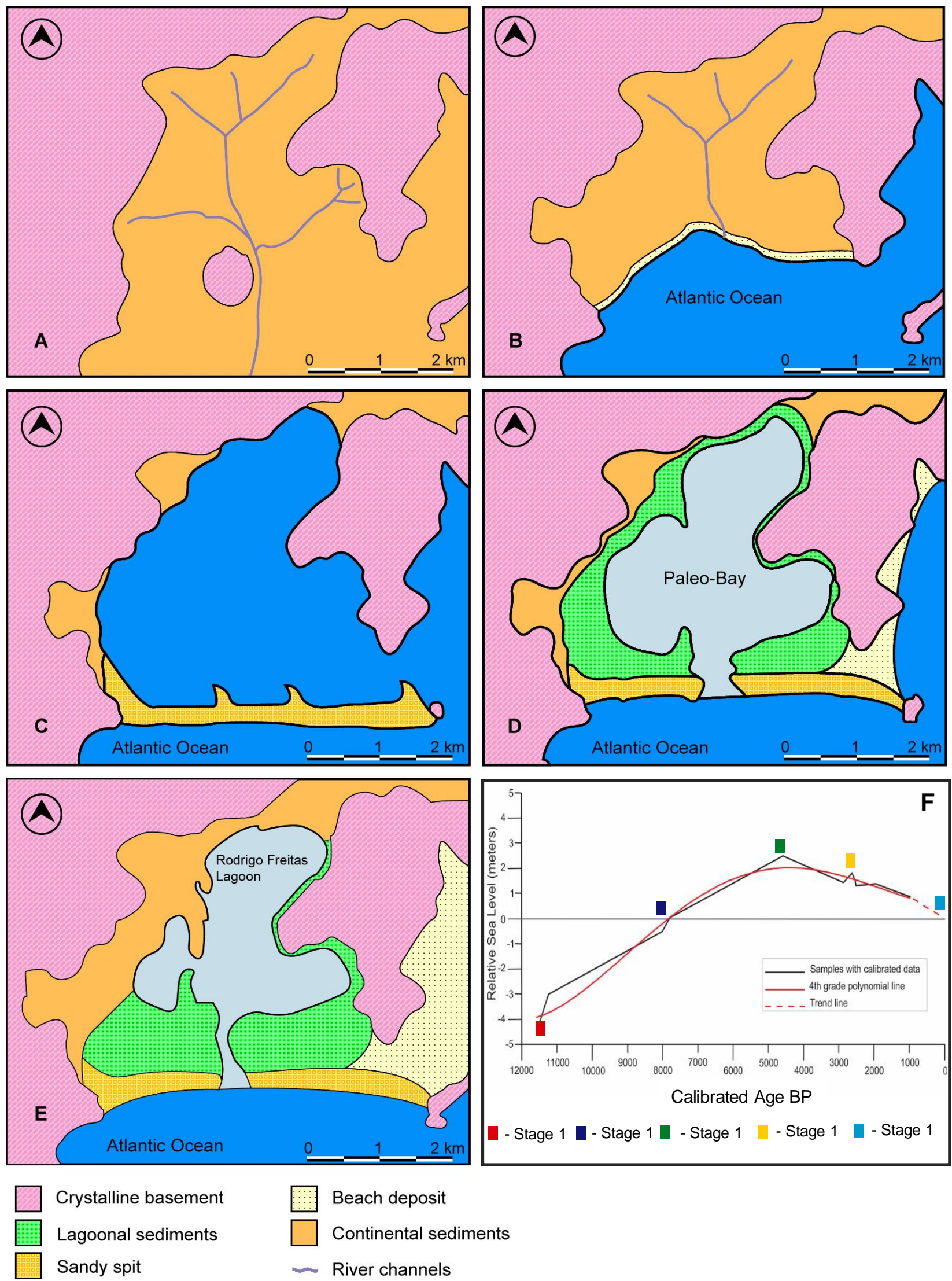

Fig. 4. Paleoenvironmental sketches for five Holocene stages proposed for the Southern Zone of the Rio de Janeiro City (A, B, C, D and $\mathrm{E})$. In F is presented the Holocene RSL curve proposed by Castro et al. (2014), highlighting the identified stages in this work. 
Tab. 2. Radiocarbon ages obtained from the mollusk shell samples. The radiocarbon age with 1 and 2 sigma calibration are also presented in this table.

\begin{tabular}{|c|c|c|c|c|c|c|}
\hline Core & $\begin{array}{l}\text { Depth } \\
\text { (m) }\end{array}$ & $\begin{array}{c}\text { Conventional } \\
\text { Radiocarbon Age BP }\end{array}$ & $\begin{array}{l}\text { Radiocarbon Age } 1 \\
\text { Sigma Calibration }\end{array}$ & $\begin{array}{c}\text { Radiocarbon Age } 2 \\
\text { Sigma Calibration }\end{array}$ & $\begin{array}{c}\text { Mean } \\
\text { Probability }\end{array}$ & $\begin{array}{l}\delta^{13} \mathrm{C} \\
(\%)\end{array}$ \\
\hline ZS-01 & $16.00-16.45$ & $7,220 \pm 25$ & $5,701-5,604$ & $5,751-5,538$ & 5,649 & 0.4 \\
\hline ZS-01 & $17.00-17.45$ & $7,200 \pm 25$ & $5,688-5,584$ & $5,728-5,523$ & 5,632 & 0.1 \\
\hline ZS-02 & $22.00-22.39$ & $5,930 \pm 25$ & $4,349-4,244$ & $4,435-4,193$ & 4,303 & 2.6 \\
\hline ZS-04 & $8.00-8.45$ & $3,150 \pm 25$ & $923-802$ & $1,007-773$ & 876 & 1 \\
\hline ZS-05 & $4.00-4.45$ & $580 \pm 25$ & $1,778-1,782$ & $1,715-1,950$ & 1,842 & 0.1 \\
\hline ZS-05 & $13.00-13.45$ & $810 \pm 25$ & $1,538-1,648$ & $1,488-1,682$ & 1,589 & 0.8 \\
\hline ZS-06 & $18.00-18.45$ & $4,230 \pm 25$ & $2,334-2,158$ & $2,437-2,093$ & 2,250 & 1.5 \\
\hline ZS-06 & $26.00-26.45$ & $8,290 \pm 25$ & $6,831-6,635$ & $6,969-6,591$ & 6,750 & 0.2 \\
\hline ZS-06 & $27.00-27.45$ & $8,710 \pm 25$ & $7,429-7,256$ & $7,473-7,154$ & 7,328 & 2.6 \\
\hline ZS-09 & $10.28-10.51$ & $6,270 \pm 25$ & $4,729-4,586$ & $4,794-4,517$ & 4,461 & 3.2 \\
\hline
\end{tabular}

The age obtained for the ZS-06 profile was 7,429-7,154 years cal BP, marking the moment when the RSL surpassed the current zero for the first time. Coastlines of previous beaches were recognized through the presence of beachrocks, whose shells that are part of the sedimentary framework had ages varying between $6,221-6,085$ years cal BP and 4,729-4,586 years cal BP. The ages of these rocks indicate that the shells belonging to the rocks framework were deposited during the Holocene transgression, between the transition from open ocean to lagoonal environments. Castro et al. (2014) emphasizes that the beachrocks are excellent markers of past beaches.

Stage 3. The sea level continued to rise until the Holocene Maximum Transgression (Suguio et al., 1985) that occurred, according to Castro et al. (2014), between 5,500- and 4,500years BP. In this phase, a large area of the coastal plain of the Rodrigo de Freitas Lagoon, Jardim Botânico, Humaitá, Gávea, Leblon and Ipanema regions was flooded (Fig. 4C). Sediments of marine environment were settled on continental sediments and parts of the crystalline basement. Cunha et al. (2017) characterized the sediments of this evolutionary stage as quartz sands of medium granulation, with fragmented shells, as sedimentary products of open marine environment. A similar observation was done by Castro et al. (2014), in Rio Grande do Sul region.

Stage 4. After the mid-Holocene sea-level maximum, with the gradual lowering of the RSL, a barrier island was developed from the sediments provided from the east-west longshore drift (Fig. 4C). Yet, with the RSL slightly above the current one, longitudinal eolian deposits and the coastal strings of the Ipanema and Leblon sector were developed, in the Southern Zone of the Rio de Janeiro City, nowadays occupied by the urbanization. The sandy layers constituted by medium sand denote the sedimentation process that led to the formation of small longitudinal dunes.

The gradual lowering of the RSL gave rise to: i) exposure to subaerial processes of marginal bottom sediments of the Rodrigo de Freitas Lagoon; ii) the coastline migration towards the sea; iii) a paleo-bay which was connected to the ocean through a paleo-channel formed by the breaking of the barrier island developed in the stage 3 (Fig. 4D).

Stage 5. The regression ended about 3,000 years BP ago (Castro et al., 2014). With the gradual lowering of the RSL (Fig. 4E): i) a large area of the marginal bottom sediments of the paleo-bay outer sector were exposed to subaerial processes; ii) the alluvial- colluvial slopes advanced towards the Rodrigo de Freitas Lagoon in the north and northwest segments causing the narrowing of the Jardim de Alah channel with the open sea; iii) the designed lagoon was then silted in the central zone by mud enriched in organic matter and developed peat in the margins.

\section{Conclusion}

The combination of geological - geotechnical data complemented by calibrated geochronological data enabled the elaboration of a Holocene 2D-paleoenvironmental reconstruction model for the Southern Zone of the Rio de Janeiro City. This model is composed by five distinct stages of Holocene geological evolution, identified in the study area. The first stage is marked by continental sedimentation evidenced by sediments deposited in paleo alluvial plains in the Pleistocene - Holocene Transition. 
The second stage marks the beginning of the relative sea level rise. The main evidence of this stage is the formation of a paleo-bay. The third phase corresponds to the maximum peak of the RSL, flooding the entire region, thus marking the mid-Holocene maximum transgression. The fourth stage is defined by the gradual sea level lowering, identified in the 2D-model by the formation of a paleo-bay. The fifth and last stage corresponds to the current configuration of the coastline.

The generated 2D-model is of extreme importance for the understanding of the variations of the RSL and future prognoses, mainly in densely occupied areas such as the Southern Zone of the City of Rio de Janeiro.

\section{Acknowledgment}

The authors thank to Fundação de Amparo à Pesquisa do Estado do Rio de Janeiro - FAPERJ and to Conselho Nacional de Desenvolvimento Científico e Tecnológico of Brazil (CnPQ) (project process \# 443662/2018-5) for financial support. Virginia Martins and Mauro Geraldes would like to thank the CnPQ for the research grants (process \# 301588/2016-3 and process \# 301470/2016-2, respectively).

\section{References}

Alves, E., Macario, K., Souza, R., Pimenta, A., Douka, K., Oliveira, F., Chanca, I., Angulo, R., 2015. Corrigendum to 'Radiocarbon reservoir corrections on the Brazilian coast from prebomb marine shells'. Quaternary Geochronology 29, 30-35.

Angulo, R.J., Lessa, G.C., de Souza, M.C., 2006. A critical review of mid- to late-Holocene sea-level fluctuations on the eastern Brazilian coastline. Quaternary Science Review 25, 486-506. https://doi.org/10.1016/j.quascirev.2005.03.008

Angulo, R.J., de Souza, M.C., Barboza, E.G., Rosa, M.L.C.C., Fernandes, L.A., Guedes, C.C.F., Oliveira, L.H.S., Manzolli, R.P., Disaró, S.D., Ferreira, A.G., Martin, C.M., 2018. Quaternary sea level changes and coastal evolution of the Island of Trindade, Brazil. Journal of South American Earth Sciences 84, 208-222. https://doi.org/10.1016/j.jsames. 2018.04.003

Bezerra, F.H.R., Barreto, A.M.F., Suguio, K., 2003. Holocene sealevel history on the Rio Grande do Norte State coast, Brazil. Mar Geol. 196:73-89. https://doi.org/10.1016/S00253227(03)00044-6

Boski, T., Bezerra, F.H.R., de Fátima Pereira, L., Souza, A.M., Maia, R.P., Lima-Filho, F.P., 2015. Sea-level rise since $8.2 \mathrm{ka}$ recorded in the sediments of the Potengi-Jundiai Estuary, NE Brazil. Marine Geology 365, 1-13. https://doi.org/10.1016/j.margeo.2015.04.003

Calheiros, A.L.S., 2006. Variações do nível relativo do mar nos últimos 7.000 anos A.P. na planície costeira de Jacarepaguá Rio de Janeiro. MsD Thesis, Instituto de Geociências, Universidade Federal do Rio de Janeiro, 130 p.

Carelli, S.G., Rocha, P.L.F., Roncarati, H., 2012. Evolução holocênica da planície costeira de Itaguaí, Baía de Sepetiba/RJ baseado em evidências geológicas, geocronológicas e geofísicas. In: Rodrigues, M.A., Pereira, S.D., Santos, S.B.

\section{RESEARCH PAPER}

(Eds.), Baía de Sepetiba: estado da arte. Rio de Janeiro, Corbã, pp. 5-102.

Castro, J.W.A., Senra, M.C.E., Ramos, R.R.C., 2006. Coquinas from the Paleo lagoon of the Tauá-Pântano da Malhada Reserve, State of Rio de Janeiro - A record of Holocene climatic optimum. In: Winge, M., Schobbenhaus, C., BerbertBorn, M., Queiroz, E.T., Campos, D.A.R.G., Fernandes A.C.S. (Ed.) Geological and Palaeontological Sites of Brazil.

Castro, J.W.A., Suguio, K., Cunha, A., Guedes, E., Tâmega, F.T.S., Rodriguez, R.R., 2012. Rochas de praia (beachrocks) da Ilha de Cabo Frio, Arraial do Cabo: registo geológico ímpar da transição Pleistoceno - Holocêno no estado do Rio de Janeiro. Anuário do Instituto de Geociências 35(1), 236-241.

Castro, J.W.A., Suguio, K., Seoane, J.C.S., Cunha, A.M., Dias, F.F., 2014. Sea-level fluctuations and coastal evolution in the state of Rio de Janeiro, southeastern Brazil. Anais da Academia Brasileira de Ciências 86(2), 671-683.

Coutinho, N.M., 2007. Erosão e deposição de sedimentos no arco de praia da Barra da Tijuca - Recreio dos Bandeirantes, Rio de Janeiro - RJ. MsD Thesis, Universidade Federal do Rio de Janeiro, 489 p.

Cunha, A.M., Castro, J.W.A., Pereira, F.M.B, Carvalho, M.A., Suguio, K., 2017. Variações do nível relativo do mar durante o Holoceno na bacia hidrográfica do rio Uma, registro de Cabo Frio - Rio de Janeiro: aspectos sedimentológicos, faciológicos e geocronológicos. Revista Brasileira de Geomorfologia 8, 143 154.

Dantas, M.E., 2001. Geomorfologia do Estado do Rio de Janeiro. In: Serviço Geológico do Brasil - CPRM [eds.], Rio de Janeiro. Brasília, CPRM, pp. 96-170.

Dias, F., 2009. Variações do nível relativo do mar na planície costeira de Cabo Frio e Armação dos Búzios - RJ: reconstrução paleoambiental holocênica e cenários futuros. PhD Thesis, Instituto de Geociências, Universidade Federal do Rio de Janeiro, $146 \mathrm{p}$.

Dias, F.F., Castro, J.W.A., Seoane, J.C.S., Camargo, L.H.R., 2009. Indicadores de mudanças climáticas e de variações do nível do mar na costa do Rio de Janeiro: aquecimento ou resfriamento? Revista Eletrónica de Geografia 1(1), 21-32.

Elias, S.A., 2007. Encyclopedia of Quaternary Science. Elsevier Ltd., 3576 p.

Fairbanks, R.G., 1989. A 17,000-year glacio-eustatic sea level record: Influence of glacial melting rates on the Younger Dryas event and deep ocean circulation. Nature 342, 637-642.

Flemming, N.C., Harf, J., Moura, D., Burgess, A., Geofrey, N. Bailey, G.N. (Eds.), 2017. Submerged Landscapes of the European Continental Shelf: Quaternary Paleoenvironments, First Edition. John Wiley \& Sons Ltd.

Flexor, J. M., Martin, L., Suguio, K., José, M.L., 1984. Gênese dos cordões litorâneos da parte central da costa Brasileira. In: Anais do Congresso Brasileiro de Geologia, Rio de Janeiro, 1, pp. 105-118.

Heilbron, M., Eiraldo, L.G., Almeida, J.C.H. [orgs], 2016. Mapa geológico e de recursos minerais do estado do Rio de Janeiro, escala 1:400.000. Programa de Geologia do Brasil, Mapas Geológicos Estaduais. CPRM - Serviço Geológico do Brasil, Superintendência Regional de Belo Horizonte.

Heilbron, M., Pedrosa-Soares, A.C., Campos Neto, M.C., Silva, L.C., Trouw, R.A.J., Janasi, V.A., 2004. Província Mantiqueira. 
In: Mantesso-Neto, V., Bartorelli, A., Carneiro, C.D.R., Brito Neves B.B. [eds.], Geologia do Continente Sul-Americano: Evolução da obra de Fernando Flávio Marques de Almeida. São Paulo, Editora Beca, pp. 204-234.

Jesus, P.B., Dias, F.F., Muniz, R.A., Macário, K.C.D., Seoane, C.S., Quattrociocchi, D.G.S., Cassab, R.C.T., Aguilera, O., Souza, R.C.C.L., Alves, E.Q., Chanca, I.S., Carvalho, C.R.A., Araujo, J.C., 2017. Holocene paleo-sea level in southeastern Brazil: an approach based on vermetids shells. Journal of Sedimentary Environments 2 (1), 35-48. htps://doi.org/10.12957/jse.2017. 28158

Khan, N.S., Ashe, E., Shaw Vacchi, M., Walker, J., Peltier, W.R., Kopp, R.E., Horton, B.P., 2015. Holocene Relative Sea-Level Changes from Near-, Intermediate-, and Far-Field Locations. Current Climate Change Reports 1 (4), 247-262. https://doi.org/10.1007/s40641-015-0029-z

Lamego, A.R., [ed.] 2007. Setores da evolução fluminense. Volume 2: O Homem e a Restinga. IBGE, Rio de Janeiro, 227 p.

Lamego, A.R., 1945. Ciclo evolutivo das lagunas Fluminenses. Rio de Janeiro, DNPM, Boletim 118, 45 p.

Maia, M.C.A.C, Martin, L., Flexor, J.M., Azevedo, A.E.G., 1984. Evolução Holocênica da planície costeira de Jacarepaguá (RJ). In: Anais do Congresso Brasileiro de Geologia, Rio de Janeiro, 1, pp. 105-118.

Malta, J.V., 2017. Rochas de praia "beachrocks" do litoral do estado do Rio de Janeiro: aspectos geológicos, geocronológicos paleoambientais. $\mathrm{PhD}$ Thesis, Instituto de Geociências, Universidade Federal do Rio de Janeiro, 119 p.

Malta, J.V., Castro, J.W.A., Oliveira, C.A., Reis, C.C., 2017. Rochas de praia "beachrocks" da Ilha de Cabo Frio - litoral do estado do Rio de Janeiro - Sudeste Brasileiro: gênese e geocronologia. Revista Brasileira de Geomorfologia 18 (2), 397-409.

Mansur, K.L., Ramos, R.R.C., Godoy, J.M.O., Nascimento, V.M.R., 2011. Beachrock de Jaconé, Maricá e Saquarema - RJ: importância para a história da ciência e para o conhecimento geológico. Revista Brasileira de Geociências 42 (2), 290-303.

Mörner, N.-A., 1984. Planetary, solar, atmospheric, hydrospheric and endogene processes as origin of climatic changes on the Earth. In: Mörner, N.-A. and Karlén, W. (Eds.), Climatic Changes on a Yearly to Millennial Basis, Reidel, Dordrecht, pp. 637-651.

Patzkowsky, M.E., Holland, S.M., 2012. Stratigraphic Paleobiology. Chicago: University of Chicago University Press. p. 32.
Pereira, E., Braga, P.M.C., Mendes, C.T., Bergamaschi, S., 2012. Sedimentação Quaternária na planície costeira de Jacarepaguá e Guaratiba (Estado do Rio de Janeiro). In: Rodrigues, M.A., Pereira S.D., Santos S.B. (Eds.), Baía de Sepetiba: estado da arte. Rio de Janeiro, Corbã, pp. 63-82.

Pereira, S.D., Santos, S.B., 2012. Restos de moluscos na baía de Sepetiba como indicadores de alterações pretéritas da linha de costa no Holocêno. In: Rodrigues, M.A., Pereira S.D., Santos S.B. (Eds.), Baía de Sepetiba: estado da arte. Rio de Janeiro, Corbã, pp. 105-111.

Pirazzoli, P.A., 1991. World Atlas of Holocene Sea Level Changes. Elsevier, Amsterdam.

Ramsay, P.J., Cooper, J.A.G., 2002. Late Quaternary Sea-Level Change in South Africa. Quaternary Research 57, 000-000 https://doi.org/10.1006/qres.2001.2290

Roncarati, E., Carelli, S.G., 2012. Considerações sobre o estado da arte dos processos geológicos Cenozoicos atuantes na Baía de Sepetiba. In: Rodrigues, M.A., Pereira S.D., Santos S.B. (Eds.), Baía de Sepetiba: estado da arte. Rio de Janeiro, Corbã, pp. 13-36.

Roncarati, H., Neves, L.E., 1976. Estudo preliminar dos sedimentos recentes superficiais da Baixada de Jacarepaguá Município do Rio de Janeiro (Projeto Jacarepaguá). Rio de Janeiro, CENPES/PETROBRAS, 89 p.

Rovere, A., Stocchi, P., Vacchi, M., 2016. Eustatic and Relative Sea Level Changes. Current Climate Change Reports. Springer International Publishing AG 2016. https://doi.org/10.1007/s40641-016-0045-7

Ruellan, F., 1944. A evolução geomorfológica da Baía de Guanabara e das regiões vizinhas. Revista Brasileira de Geologia 4, 3-66.

Suguio, K., 2003. Tópicos de geociências para o desenvolvimento sustentável - As regiões litorâneas. Revista do Instituto de Geociências, USP, 2(1), 40 p. https://doi.org/10.11606/ issn.2316-9109.v2i0p1-40

Suguio, K., Martin, L., Bittencourt, A.C.S.P., Dominguez, J.M.L., Flexor, J-M., Azevedo, A.E.G., 1985. Flutuações do nível relativo do mar durante o Quaternário superior ao longo do litoral brasileiro e suas implicações na sedimentação costeira. Revista Brasileira de Geologia 15(4), 273-286.

Villena, H.H., Pereira, S.D., Chaves, H.A.F., Dias, M.S., Guerra, J.V., 2012. Indícios da variação do nível do mar na Baía de Sepetiba. In: Rodrigues, M.A., Pereira S.D., Santos S.B. (Eds.), Baía de Sepetiba: estado da arte. Rio de Janeiro, Corbã, pp. 39-62. 